\title{
The physician as coworkers see him
}

A nd they saw him, he walked to the hospital two miles to get the alcohol out of him, in the mornings, he took two aspirin and never doubted that he would get drunk that day, but he had work to do, rounds to do, patients to see, he had to be the doctor, the surgeon, and everyone knew, and he was past the point of caring, the hospital knew and it excused him because of his skill, his local renown, his ability to walk in the hospital as if he were not craving a drink, desperately needing one to bathe the nerves, something to steady his hands: it was two days this time, two days since he had a drink, he had a surgery scheduled on the mayor this morning and he knew they wouldn't let him operate if he was shaking, but coffee only made the shaking worse, and he stared at his hands, willing them to come to rest, but they shook the more he concentrated, defying him, betraying him, telling him that he drank too much but he already knew that, he had his habit and he indulged it as the natural state of affairs, as a disease running its course, as if he nursed his own affliction, and he knew that this day could be his last as a doctor, as all of them could be, all he needed was one bad outcome and the administration would hang him, he was notorious, he was weakening and he was failing and he knew that if there was a blessed cure it was his drink, it was him at 3 am looking in the mirror and wondering how he got here, to this point, and then realizing just how he had done it, and he saw the drink in his hand, and he knew that this mayor would be his last case, he swore it to himself, he would remove the small polyp and he would walk out of the hospital and never come back, starting at the barrooms and entering a blackout and never coming out, never blessedly coming out, he'd end up in Scranton or Biloxie or New York and he'd come to in an alley, in a hospital, in a coffin, and he'd remember everything he heard they said about him, that he

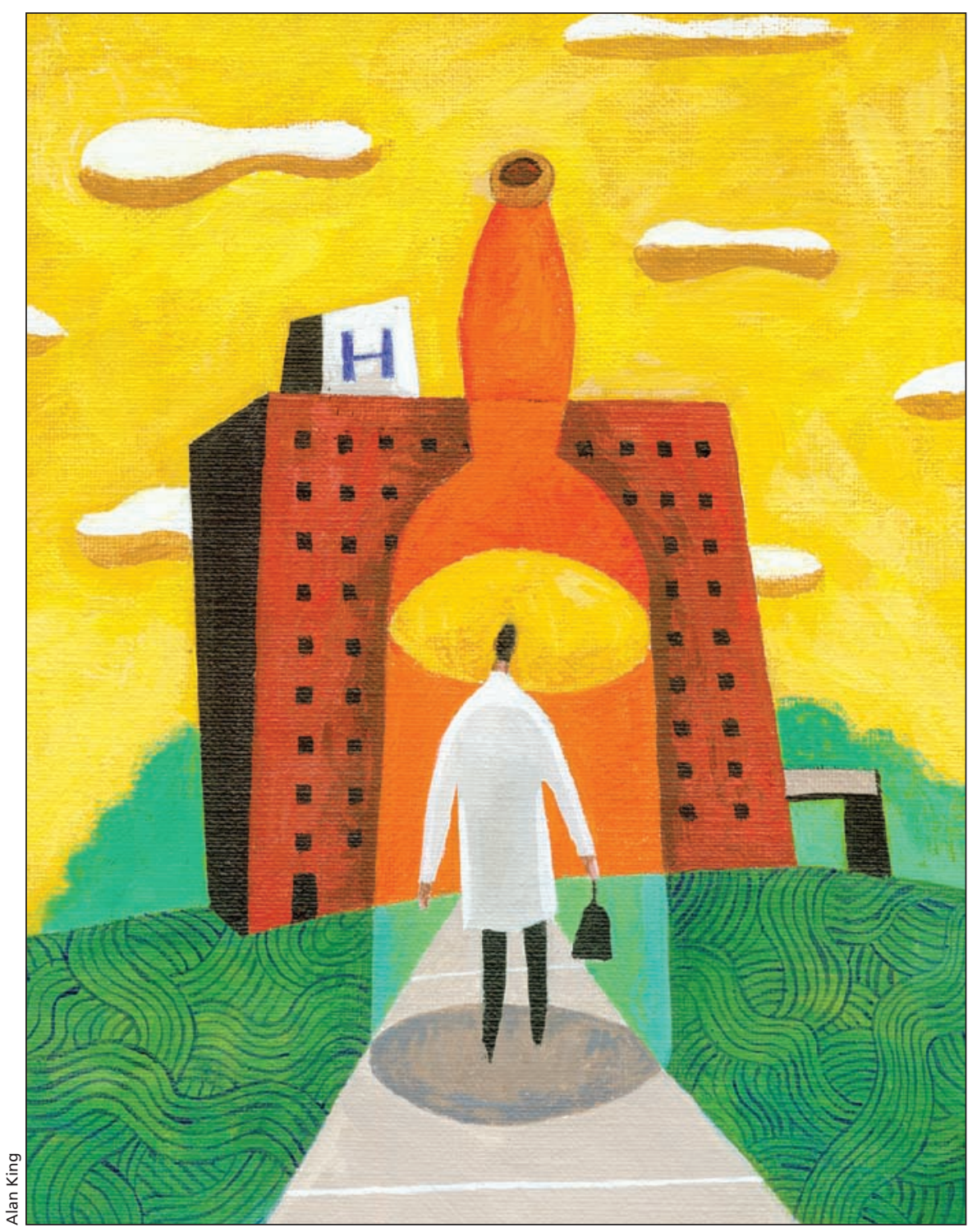

drank in between surgeries, that he had a tumbler in his office for sprucing up, that he was a bad bad doctor, someone who could end up in the infirmary himself from a night of carousing with lacerations on his face and two brilliant black eyes and having no idea how any of it happened, any of it, and he was walking to the hospital, grim this time, his arms shoved in his pockets so no one would see the shaking, bearing down and willing himself to walk, thinking of his wife who, like the rest of the world, had given up on him save for his minor surgical skill, his grace with scalpel, the last thing he had left, and he felt it leaving him now, leaving with every step, the hospital in Akron looming and laughing and about to swallow him through its thick double doors, and the mayor was probably waiting in an anteroom, fearing the state of his doctor, knowing he was a drunk but needing him just the same, and when Dr. Smith entered the door, 
dressed in surgical garb, he stretched out his right hand and asked the mayor how he was doing today, and the mayor said Fine. Just fine. And the doctor shook his hand with a firm grip that had to be the grip of hell, and his hands did not shake, they had passed through the doors of the hospital, that hallowed ground, and here they were ready to earn another drink, another daily reprieve, and the mayor knew that he would come out all right, that the tumour would be removed and he would indeed be fine.

The nurses watched that handshake, watched to see the degree of tremor, wondering if this could go as planned. Some days the staff whispered. Some days I just wished that Dr. Smith had a couple before he came to the OR just to get that tremor out of the way, but today he had not had a drink and his judgment was intact, if it could be said that he had any at all, and Dr. Smith knew, as he picked up the snare, that he was dying. And when the surgery was over, a great success, the tissue in the bottle for safekeeping, he knew that he really didn't know where he was going next, if he would say goodbye to these people, or if he'd stare at the hospital walls for a few minutes before leaving, or if he'd walk the shortest route to outside and never look back.

Before he could leave, there was a call direct into the OR. It was the hospital administrator, asking to see him immediately. Dr. Smith knew that he probably would not survive this meeting; the nurses watched him closely as the administrator made his summons. Dr. Smith, whose lanky frame belied years of burden, became straighter with the news: when operating on the mayor, he seemed to be defeating himself, bending over more and more, listing to the left. Dr. Smith went to the sink, removed his gloves, and washed his hands as he had done after a thousand of these procedures. His hands moved slowly and smoothly over one another, washing off the soap. He was clean. He walked up the hall to the gilt-edged office door that was Always open to our staff anytime and without knocking he opened it and saw the administrator engaged in a phone call, laughing as if he had never touched a cancer in men, a cancer that claims all, and Dr. Smith sat down, watching as the administrator finished his call, taking his time, sending the message that Dr. Smith was one of a thousand administrative duties he'd discharge today.

"Dr. Smith, we know you drink and that it's affecting your work. Our privileges committee has met and has decided that you can no longer offer surgeries at our institution."

Dr. Smith said nothing.

"Dr. Smith, we also know that you are a talented surgeon, an affable man, but we feel your position is hopeless and have to act now."

Dr. Smith was thinking of gin, of straight gin, of how opportune it would be if he had some right now. He even thought he'd offer some to the administrator, if he had some. Gin for the gullet, without swallowing, straight into the stomach; no food yet, so it'd be absorbed even faster, gin for the mood, gin for the day and night, gin for the gauze over his eyes on waking and gin to raise the hammer of sleeping. Where was this gin? Did he have enough money for the liquor store? Or did he spend it all last night? He was worrying too much about his hands that morning to worry about how much money he had left over. He pulled out his wallet in front of the administrator, and as the administrator was talking, babbling about risk management and reputation, he looked for bills. There were none. He could not purchase bliss.

Dr. Smith, at this moment, thought about pleading for his job. About protestations that he would change. That he would be the best surgeon this damn hospital, this city, had ever seen, that he'd lick this problem and be the reason donors poured money in; but he knew from past history that he'd only drink to all of that, that it would evaporate after the first drink, and that in blackouts are the annals of misery. He asked the administrator for 20 dollars.

The administrator looked surprised; he had expected a defense, an attempt. The administrator said he only had ten dollars and Dr. Smith said he'd take that and once it was passed, Dr. Smith walked back to the mayor's bed, the nurses telling him that the mayor was recovering nicely, that he was out of the fog of the drugs and was chatting them up, a very randy mayor. The intravenous dripped an off-green liquid and the mayor, an unsettlingly gregarious man, still weak, and still praying, asked him if he got it all and Dr. Smith said I did, I got it all.

Then Dr. Smith knew he was free and at that moment a procession of doctors lined up on the right, all the doctors he had ever known, all the doctors who had ever witnessed him. And then, a procession of all the nurses who had taken orders from him and who had ever guessed at the quantities he had drunk the night before, wondered if he'd had a drink that morning, if he was a good doctor as everyone thought he was (though there was something intrinsic preventing that). Nurses and doctors lined the hallways, silent, silent as they always had been except when not in his presence, nurses and doctors opening the double doors for him, wondering if they should, this last time, bear him aloft, but in the end they let him go through alone and the doors closed and the silence ended. There was the sound of birds and cars and ambulances, the sounds of orderlies smoking in the shade, the sounds of obliviating cares.

Now that the Mayor was free Dr. Smith knew he had no further obligation and he walked on a meandering path, stopping to look at the trees planted on the grounds by donors wishing to remember their saintly grandmother, their tragic child, their chief source of grief in this world, or their joy, and Dr. Smith knew where he was headed, eventually, and the day was cold, he put his hands in his pockets.

Later that night, when the administrator kissed his wife and went to bed, he told her that he had fired Dr. Smith that day, that he figured Smith went where he always went, to the hotel, and his wife, who shouldn't know about Dr. Smith but did, told her husband that he did the right thing, and Dr. Smith would have agreed with her, if he had heard.

\section{Shane Neilson MD}

Family physician and poet Guelph, Ont.

CMAJ 2014. DOI:10.1503/cmaj.100834 